\title{
ECONOMIC AND SOCIAL EXCHANGE OF PERSONAL DATA AND THE RISKS OF THEIR PROTECTION
}

\author{
Nino Tskhovrebashvili \\ Doctor of business administration \\ Teaching and Research Attache, PhD student \\ University of Paris 1 Pantheon-Sorbonne, FRANCE \\ Assoc. Professor, Grigol Robakidze University
}

\begin{abstract}
For the economic sector, new technology and communication have become real challenges. Personal data has become an important key to penetrate new markets and several firms are specialized in their collections and sales. Using customer profiles, marketing departments make it easier for them to predict customer behavior and beat competitors. The free movement of goods, payments and data are increasingly common among countries and the protection of personal data is increasingly called into question. Notably, the postmandemic period has significantly increased the distance relationships and data exchange rates. This situation has also contributed to social media addiction. It should be noted that in such a period it is important to increase the level of awareness of Internet users and to be especially careful when issuing data. An important step has been the introduction of a new regulation (GDPR) in the personal data protection system since 2018, which has revised and refined the existing rules and regulations. Especially noteworthy are the Right to be forgetten and the right to data portability.
\end{abstract}

Keywords: Data protection; Social networks; GDRP; General Data Protection Regulation; Digital culture; E commerce; Right to be forgotten.

\section{Introduction}

After the creation of the EU, the movement of people, goods, various public or private services and capital became evident. For the movement of people, personal data is transferred from one state to another either through customs or through the services where the person concerned travels or works. If workers in the information industry establish themselves in another country of the Community, the data is transferred in accordance with Article 43 of $\mathrm{EC}^{13}$

According to research by IDC, a company specializing in analyzing information on the Internet, the amount of data in circulation grows by $50 \%$ each year. And it's not just always very important information, but entirely new flows of little value. In our time, there are a large number of digital sensors installed on industrial equipment, electricity meters and automobiles. These sensors can measure and transmit information about location, movement, temperature, humidity and even chemicals in the air. By connecting this information to computers, we receive "the industrial Internet". It is also because it is easier to access information that the trend of data flooding continues.

In 2017 the IDC estimated that "the market for big data technologies and services will grow at a compound annual growth rate of $26.4 \%$ to reach $\$ 41.5$ billion through 2018 , or about six times the rate of growth of

${ }^{13}$ GAILLARD Emmanuel, Racine Jean-Baptiste « Liberté de l'establishment »; Journal du droit international (Clunet), N3. 2009-07-01. 
the global information technology market". ${ }^{14}$ By 2021, global business investment in big data is expected to grow by more than $10 \%$ to $\$ 215.7$ billion, IDC researchers believe. ${ }^{15}$ Large retailers analyze sales, prices, even weather conditions as well as demographics to best tailor product selections by store and determine prices and promotion periods. Social networks, especially online dating sites, analyze lists of personal characteristics, reactions and comments, to attract large numbers of customers. Police departments in the United States analyze arrest histories, paydays, precipitation, and holidays in an attempt to predict crime and dispatch officers to these areas.

Research shows that economists find that companies that make decisions based on data analysis achieve 5$6 \%$ higher productivity than others. They assure us that Google queries have the capacity to know more than INSEE about France. The processing of data in general, including personal data, allows the control of certain markets which already transmit several information in certain fields by different electronic tools.

Online training is growing rapidly in several countries. IT gains much economic importance. IT will eventually revolutionize education and enable human resources to be mastered, but will face the issue of data protection. In general, a consumer visits websites without wanting to provide their personal data but to access certain parts of the websites, or the site administration may request personal data. The communication of this data is voluntary but if the consumer does not provide this data, he will not be able to benefit from the services offered by the sites: this is the case with the communication, the downloading of documents or the recruitment.

\section{Social networks and Data protection problems}

The issue of data protection on social networks is a matter of concern for all users. Social networks offer a possibility of communication which can threaten privacy. Personal data "images, videos, comments" become publicly available and can be examined by several services.

Sometimes it is difficult to extract information from the web once it has been published and this data often remains accessible through search engines. The practice of processing and marketing the data of users of social networks is developing. All the information that it is possible to have on an individual is retrieved.

Facebook, for example, stores all of our data on their servers. More than 600 terabytes of data are thus stored every day. Worst of all, during the presidential elections in the United States in 2016, the company "Cambridge Analytica", dedicated to the profiling of voters, seized the data of 50 million Americans, without their consent. The data was collected using an app invented by a Cambridge University researcher. 270,000 Facebook users were paid to complete a personality questionnaire and agreed to have their data collected for academic use. But the application also collected data from the Facebook friends of all these users. Following the violation of the rights of its users, the Facebook network was forced to pay the largest fine ever imposed (5 billion dollars) $)^{16}$

\footnotetext{
${ }^{14}$ S. Findling, J. C. Pucciarelli, Michael Jennett. IDC FutureScape: Worldwide CIO Agenda 2018 Predictions. https://www.idc.com/getdoc.jsp?containerId=US43203417\&pageType=PRINTFRIENDLY; [L. s. 27.11.2021].

${ }^{15}$ Big data et analytique : un marché promis à une croissance à deux chiffres 18.08. 2021

https://www.silicon.fr/big-data-analytique-croissance-414574.html\#: :text=Actualit\%C3\%A9s\%20Big\%20Data-

,Big\%20data $\% 20$ et $\% 20$ analytique $\% 20 \% 3 \mathrm{~A} \% 20$ un $\% 20$ march $\%$ C3\%A9\%20promis,une $\% 20$ croissance $\% 20 \% \mathrm{C} 3 \% \mathrm{~A} 0 \% 20 \mathrm{deux} \%$

20chiffres\&text=Selon\%20les\%20plus\%20r\%C3\%A9centes\%20pr\%C3\%A9visions,de \%20dollars\%20cette $\% 20$ ann $\%$ C3\%A9e $\%$ 202021. [L. s. 27.11.2021].

${ }^{16}$ Facebook : une amende de 5 milliards de dollars et de nouveaux garde-fous, déjà contestés 24.07.2019 https://www.lemonde.fr/pixels/article/2019/07/24/donnees-personnelles-les-etats-unis-imposent-de-nouveaux-garde-fous-afacebook-deja-contestes_5493017_4408996.html [L. s. 28.11.2021].
} 
The operators of social networks draw up personalities according to their tastes, habits, hobbies. Technologies manage analyzed data and track the various activities of Internet users in order to guide their choices. Depending on the tastes and interests of social media subscribers, advertisers can further direct their advertising to consumers. All information relating to members of social networks makes it possible to offer personalized, that is to say, targeted advertising. In France and in Europe, several people are victims of identity theft. According to the definition of the penal code, the theft of data is the act of making use via electronic information, of the data of a third party which is personal to him, with a view to undermining his honor and disturbing his life. ${ }^{17}$

We can distinguish personal identity from digital identity. In this regard, we raise another question. When you create a person on social networks, how can you talk about their rights and their personal identity? Another interesting question: is an individual's "wall" private or public? Several cases studied at the Court concerned insults uttered by employees against their boss. There is no clear concept to define the character of network walls, but according to the court's cases, the wall was considered a private place under certain conditions.

Social networks with a non-European origin, for the most part, were subject to the principles of the Safe Harbor. Social networks have an obligation to underline, in their contract, the various rights registered with their services. Networks have an obligation to determine who owns the data. This notion of property will condition the rights granted to users. It is constant that the power of the CNIL in France and its counterparts in Europe is not sufficient to push back the network giants. (GAFAM) companies are sometimes barely 20 years old (Facebook was created in 2004 and Google in 1998) and yet the capitalization of each of them, with the exception of Facebook, exceeds $\$ 1,000$ billion.

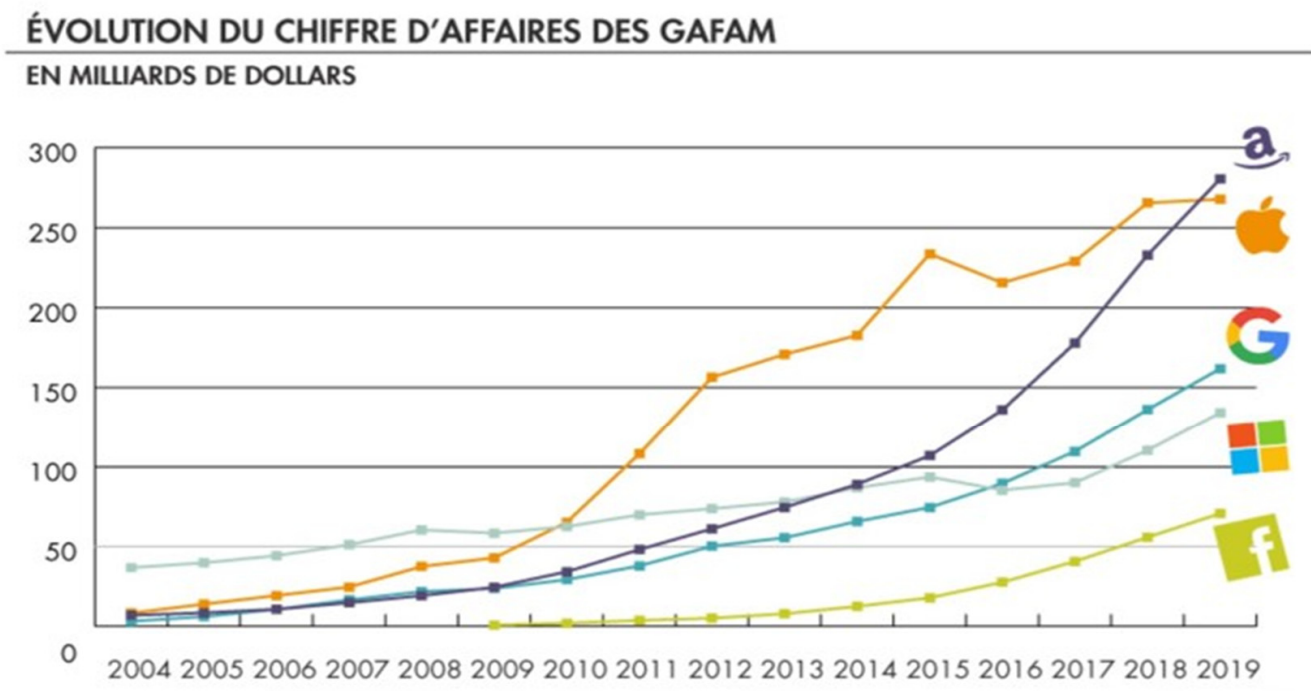

Source : lafinancepourtous, d'après Statista

It is indisputable that new rights are created to cover the new needs. It is about giving anyone the power to decide the extent to which information about them can be processed, communicated, and stored. On social

\footnotetext{
${ }^{17}$ Usurpation d'identité numérique: L'article 226-4-1 du Code pénal.
} 
networks, this right would allow any user to be able to delete all information concerning him, the right to digital oblivion is a new claim because information on the net is difficult to remove. According to research conducted by the CSA for Orange, $85 \%$ of French people say they are concerned about the protection of their data on the internet and $42 \%$ think that the situation has deteriorated in recent years ${ }^{18}$

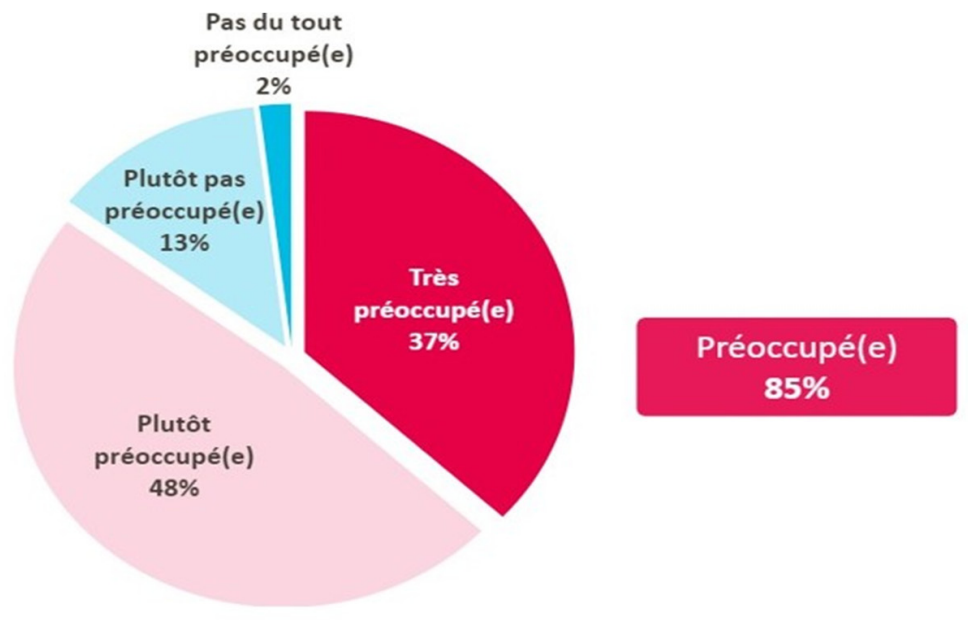

Source : Etudes de l'institut du CSA pour ORANGE ; 2014

\section{Right to be forgotten}

The right to digital oblivion responds to the concern of Internet users to control their online reputation, which is coupled with concerns around the protection of personal data. When a person logs onto a website, they leave several types of traces. Identification data, geolocation, then data intended for a circle of close friends ... These data are likely to be processed by economic players to provide an online service, distribute and generate traffic.

Beyond the certain benefits, several risks affect privacy: processing of personal data without the user's consent, an unlimited data retention period, loss of control. It is in this area that the right to digital oblivion must intervene.

At first, Google had refused to comply with the "right to be forgotten" imposed by the CNIL, "arguing that the French body was not competent" to control "the information accessible throughout the world ${ }^{19}$

After contesting the ruling, Google was forced to accept the judgment and launched an online form accessible to Europeans, allowing them to request removal of search results. A day after this decision, Google received more than 12,000 requests from European Internet users to be deleted from its search services The right to digital oblivion has thus appeared at European Union level since 2014 in the Conzales case. The Court of Justice of the European Union (CJEU) defines this right as the obligation, for a search

\footnotetext{
${ }^{18}$ Les Français et la protection des données personnelles, études de l'Institut du CSA pour Orange, 2014.

${ }^{19}$ Droit à l'oubli : la Cnil dit non au recours de Google, La Tribune, 21/09/2015 https://www.latribune.fr/technosmedias/internet/droit-a-1-oubli-la-cnil-dit-non-au-recours-de-google-506908.html, [L. s.29.11.2021].
} 
engine, to "remove from the list of results displayed following a search carried out using the name of a person, links to web pages, published by third parties. ${ }^{20}$

The right to be forgotten does not allow a user to ask a web host to delete pages, but gives the possibility to request the removal of links. The pages still exist, but are no longer referenced when searching for the person's name. We thus speak of "de-referencing". Since May 25, 2018 and the entry into force of the GDPR, the countries of the European Union have had a legal basis on the right to be forgotten and erased. (Article 17)"The data subject has the right to obtain from the controller the erasure, as soon as possible, of personal data concerning him and the controller has the obligation to erase such personal data as soon as possible. time limits, when one of the following reasons applies"21

- Personal data are no longer necessary for the purposes;

- There is no legitimate reason for the processing; ${ }^{22}$

- Personal data have been processed unlawfully;

At the social level, the right to be forgotten is a gesture of rehabilitation in society. The "right to forget" collectively imposes silence on the faults and penalties of citizens, in certain circumstances, to guarantee peace and social cohesion.

\section{Particularity of Digital culture}

Internet users' behavior is linked to the benefits they have received after sharing certain information in the past. The country's culture and business experiences influence the minds of consumers. If we look at the results from different countries, we will see that behaviors vary according to age, social culture and brand sectors. Thus, sectors play an important role in the perception of data that can be collected and shared. The attitudes of young customers with social media accounts differ from the attitudes of 60 -year-old consumers who have never had such accounts. American consumers believe that companies use their data for business purposes and expect benefits in return. China has one of the lowest sharing deficit of the three countries studied (France, United States, China) ${ }^{23}$ the French oppose the greatest resistance to data sharing, emphasizing the need to maintain control. Only $23 \%$ of French internet users say they are ready to share, compared to $61 \%$ in China and $45 \%$ in the United States.

Milad Doueihi describes digital technology as a process of emerging social norms marked by both freedom of expression and surveillance. According to the author, "the religious dimension of digital culture has the effect of leveling out differences and reducing local factors to mere superficial variations of a universal and homogeneous technological culture and its digital environment. "24

Culture can be considered as the set of distinctive features, spiritual, material, intellectual, which characterize a society. It encompasses the arts and sciences, lifestyles, laws, value systems, and beliefs. It is believed that digital culture is understood in the global dimension where the national culture, history and politics of each nation intersect. In the early days of digital history, the goal of progress was computation and decryption. The Internet was born out of an imperative to resist a nuclear attack. Researchers and engineers were mobilized and funded for the creation of the network which will become "Advanced

\footnotetext{
20, Arrête Google Spain c/ AEPD et Costeja Conzales, 13/05/2014. Demande de décision préjudicielle, introduite par l'Audiencia Nacional.

${ }^{21}$ GDPR ; Droit à l'effacement "droit à l'oubli, Article17, https://www.gdpr-expert.eu/article.html?id=17\#textesofficiels

[ L. s.29.11.2021].

${ }^{22}$ GDPR Right to object, Art. 21 https://gdpr-info.eu/art-21-gdpr/ [L. s.29.11.2021].

${ }^{23}$ F. Hanna, Etude « Value Me » de Microsoft Advertising sur la valorisation des données personnelles 20.07.2015.

${ }^{24}$ Digital Cultures, M. Doueihi, (2011a). En traduction française, La grande conversion numérique (2008, pp. 25, 26).
} 
Research Projects Agency Network. Since then, we cannot imagine our life without the internet and without connected objects. Digital culture is becoming a very delicate subject which encompasses the features of general culture and that of digital. As Cardon says: "it is important to have a variety of knowledge to live there with agility and prudence, because if we make digital, digital also makes us". ${ }^{25}$

\section{E-commerce and Data}

Data collection can be carried out simultaneously with the purchase or service process. With the procedure of the identification for the purchase or internet service one can collect the information concerning the customers which will be stored according to the interests of the merchant. Communication between computers over the internet is only possible through the use of specific protocols. The TCP / IP protocol gives the possibility of transporting information on the web and their unification at the recipient. The recipient is identified by IP. TCP / IP is the set of communication rules and is based on the concept of IP addressing. Protocols TCP / IP was created for military purpose and it meets the following criteria:

- Use of address systems

- Routing, Data flow

- Control of data transmission errors

The use of these protocols shows the transmission of various information such as IP and the language used by the program, type of use, date and time of the connection, the possible request. This information is likely to be recorded by the navigation program and by the servers. The specialists will process this data to offer potential customers other products. The representative of e-commerce, are interested in becoming a provider of personal data in our current world. Commercial internet sales sites are subject to distance selling regulations (VPC), including declarative obligations (consumer protection,) and mandatory information. The merchant must comply with the following conditions:

- Informing customers about their right to access, modify and delete the information collected;

- Have adequate information systems security;

- Indicate a data retention period;

Responsible for the online sales site which collects personal information and constitutes customer files, must make a declaration to the CNIL. (In France) The Council of Europe adopted in 2001 the Convention on Cybercrime which is often encountered in electronic commerce. It concerns not only the Member States but also Japan and the United States.

At European Union level, the legislation relating to E-Commerce is as follows:

- Directive 1999/93 on electronic signatures of December 13, 1999;

- Directive 2000/31 / EC on electronic commerce of 2000 guaranteeing legal certainty for businesses and consumers;

In French law, two laws concern electronic commerce:

- Law on electronic proof of 3 March 2000; ${ }^{26}$

- Law for confidence in the digital economy; ${ }^{27}$

25 P. Cavallar, La culture numérique selon Dominique Cardon, Culture numérique, Presses de Sciences Po, 2019.

${ }^{26}$ Loi n $^{\circ}$ 2000-230 du 13 mars 2000 portant adaptation du droit de la preuve aux technologies de l'information et relative à la signature électronique

${ }^{27}$ Loi n $2004-575$ du 21 juin 2004 pour la confiance dans l'économie numérique 
After the 90s, each consumer will be differentiated and no longer be identified as a common group. Before buying the product, he compares and thinks, his demands are increasing, he becomes independent. The companies decide to bring an offer adapted to the consumer. One-to-one marketing is individualized marketing, which should allow companies to have a personalized relationship with customers. This type of marketing represents 4 phases: Identify, differentiate, interact and personalize. CRM, a "one to one" marketing tool, is made concrete with the Internet. This tool helps to establish the database file for customer loyalty. Thus we manage to create the customer's profile by processing and using this data. The Law provides for the recognition of a right of opposition of the data subject. The commercial interest of a company is sufficient to legitimize the collection and processing of non-sensitive data relating to its current or potential customers for a marketing purpose.

The transfer of data to third parties contains a risk of potential loss of personal control over the data. The customer does not know to whom this data will be communicated and for what purpose it will be served. There will always be risks that the third party does not comply with data protection laws. despite the risks, online shopping is increasing. France is the second largest e-commerce market in Europe after the United Kingdom. ${ }^{28}$

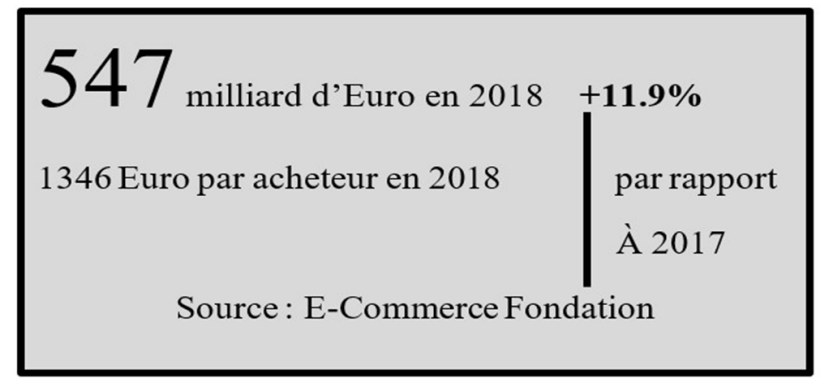

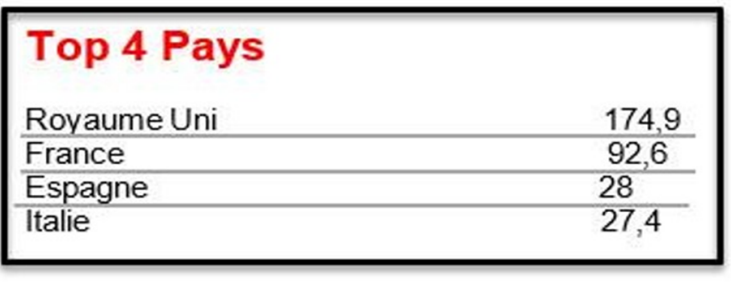

Chiffre d'affres e-commerce en 2018 en milliards d'euro; Source: Ecommerce Fondation

The most visited sites in France

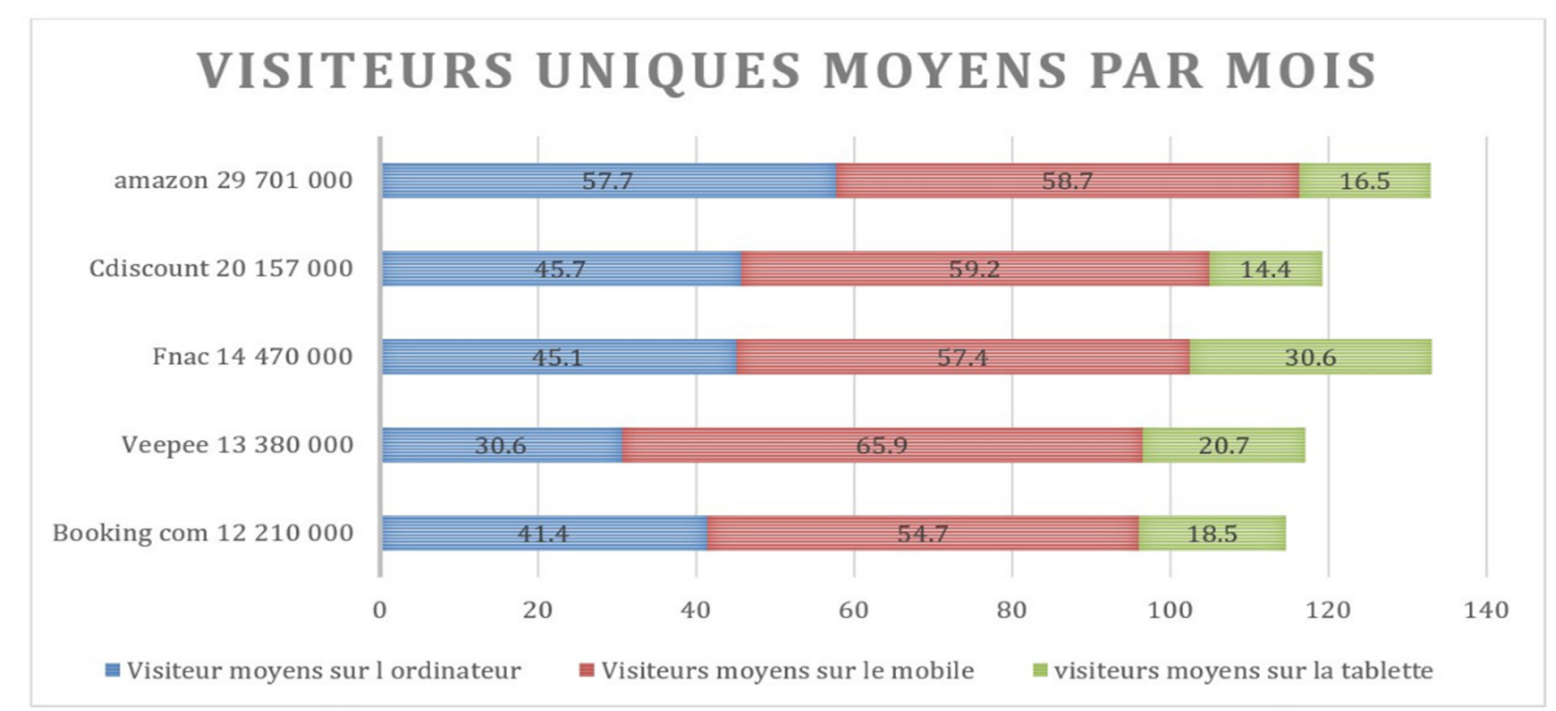

Source Médiamétrie//Net ratings Moyenne - T1 2019 France - Audience internet

${ }^{28}$ LES CHIFFRES CLÉS 2019 FÉDÉRATION E-COMMERCE ET VENTE À DISTANC https://www.fevad.com/wpcontent/uploads/2019/06/Chiffres-Cles-2019_BasDef-1.pdf [Last seen 29.11.2021]. 


\section{E-SHOPPERS IN EU-27 COUNTRIES}

Percentage of internet users that bought goods

or services online

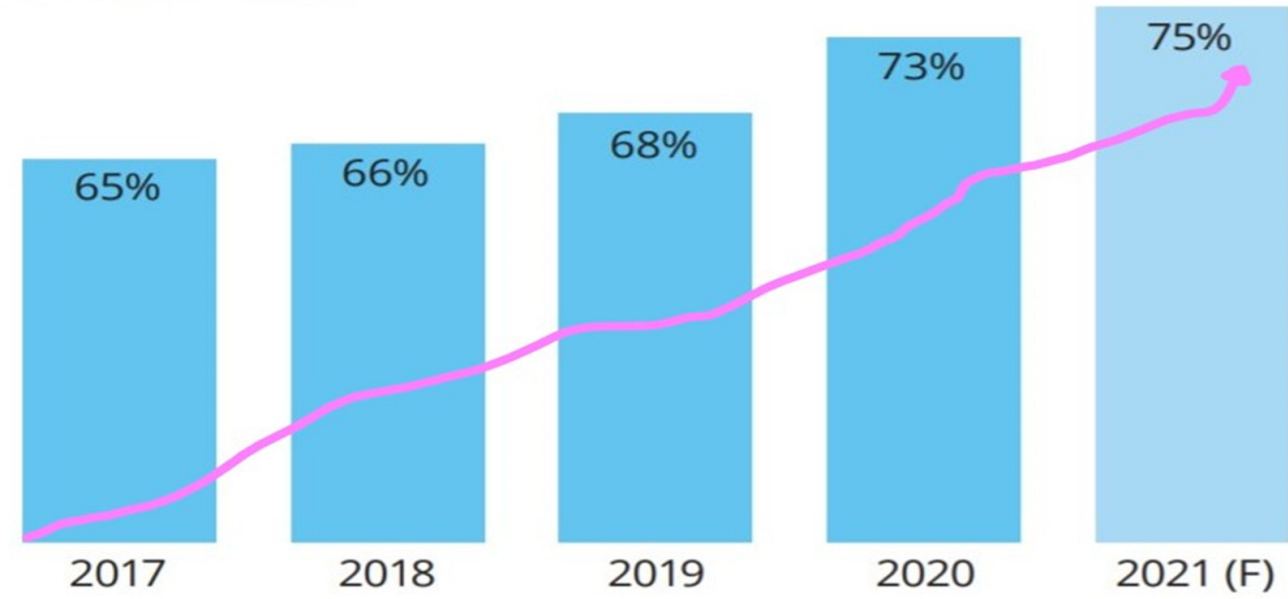

SOURCES: EUROSTAT; NATIONAL E-COMMERCE ASSOCIATIONS; STATISTA

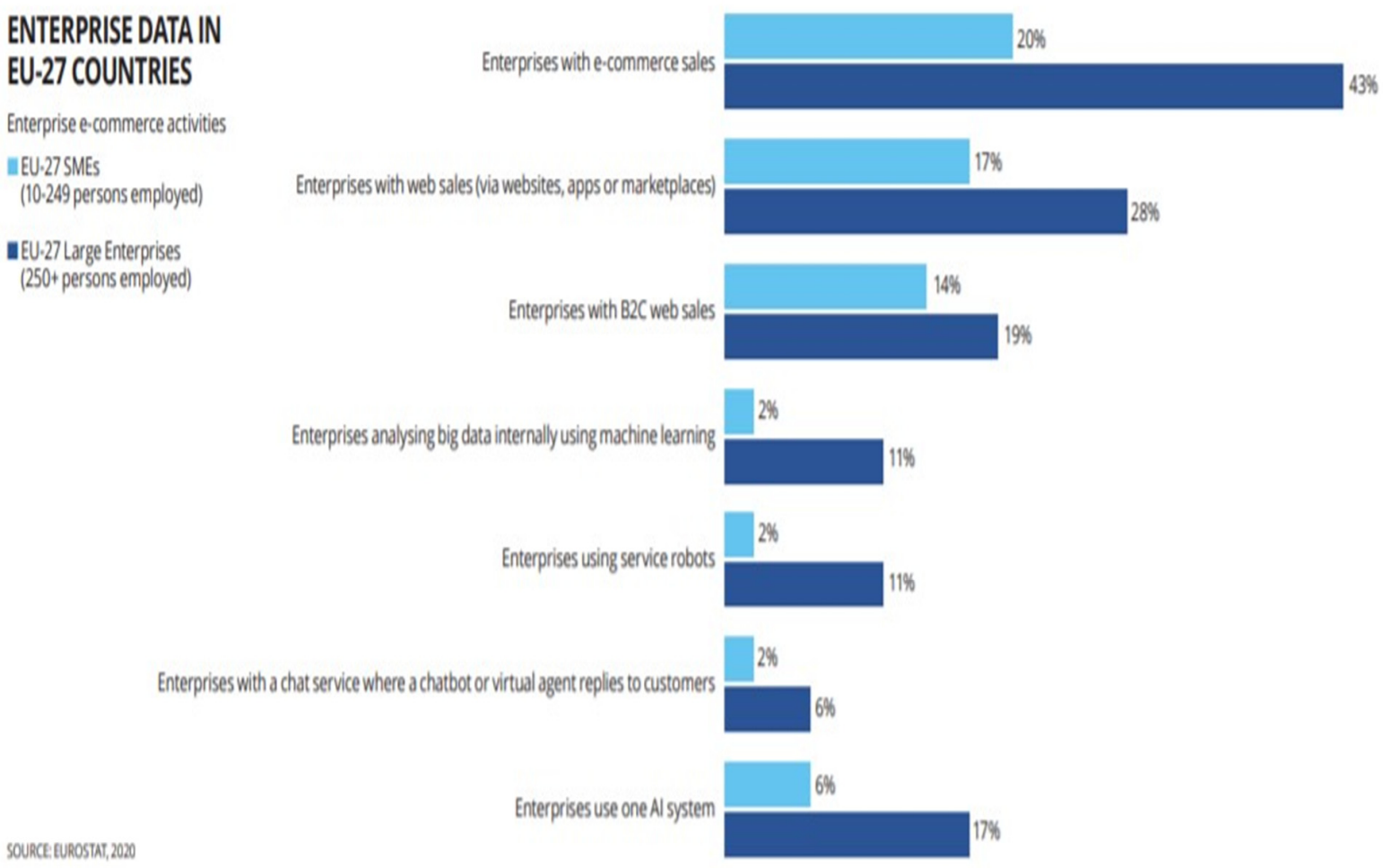




\section{Researches}

We organized a study with French (Sorbonne; Paris1; Master SIC/MIKS) and Georgian universities (GRUNI; TSU, SEU, SANGU, OPENUNI) in the years 2018-2021. Object of research was to discover the level of attitudes towards personal data protection at universities. In the Focus group there were students and professors of the institution. Age group of 20-68. Studies were about quantitative and deductive methods. Dichotomous questions were used as well as the Likert scale method to measure the range of some answers. The number of respondents was 230 . The responses were analyzed using Google's automatic summation method. We propose extract from this research in this article.

\section{Questions}

- Have you ever regretted disclosure of personal information?

- if you changed your attitude towards social networks after Facebook was fined a record $\$ 5$ billion for improper storage of user data?

- In case of improper processing of your personal data, do you intend to apply to the relevant authority for protection?

- The right to be forgotten is one of the most important points in the general regulation of personal data protection in 2018, which was used by thousands of Internet users. What is your opinion on this issue?

- Have you heard about GDPR regulation?

- In France, since 2018, there is an information system on orientation in higher education "système d'information sur l'orientation dans le supérieur". According to the creators, this system helps to see the existing problems and interests in order to improve them in the future. Complete information about each pupil and student is gathered from school to the University period. Do you think it is justified to have a similar system and use the same practice in Georgia?

\section{Have you ever regretted disclosure of personal information?}

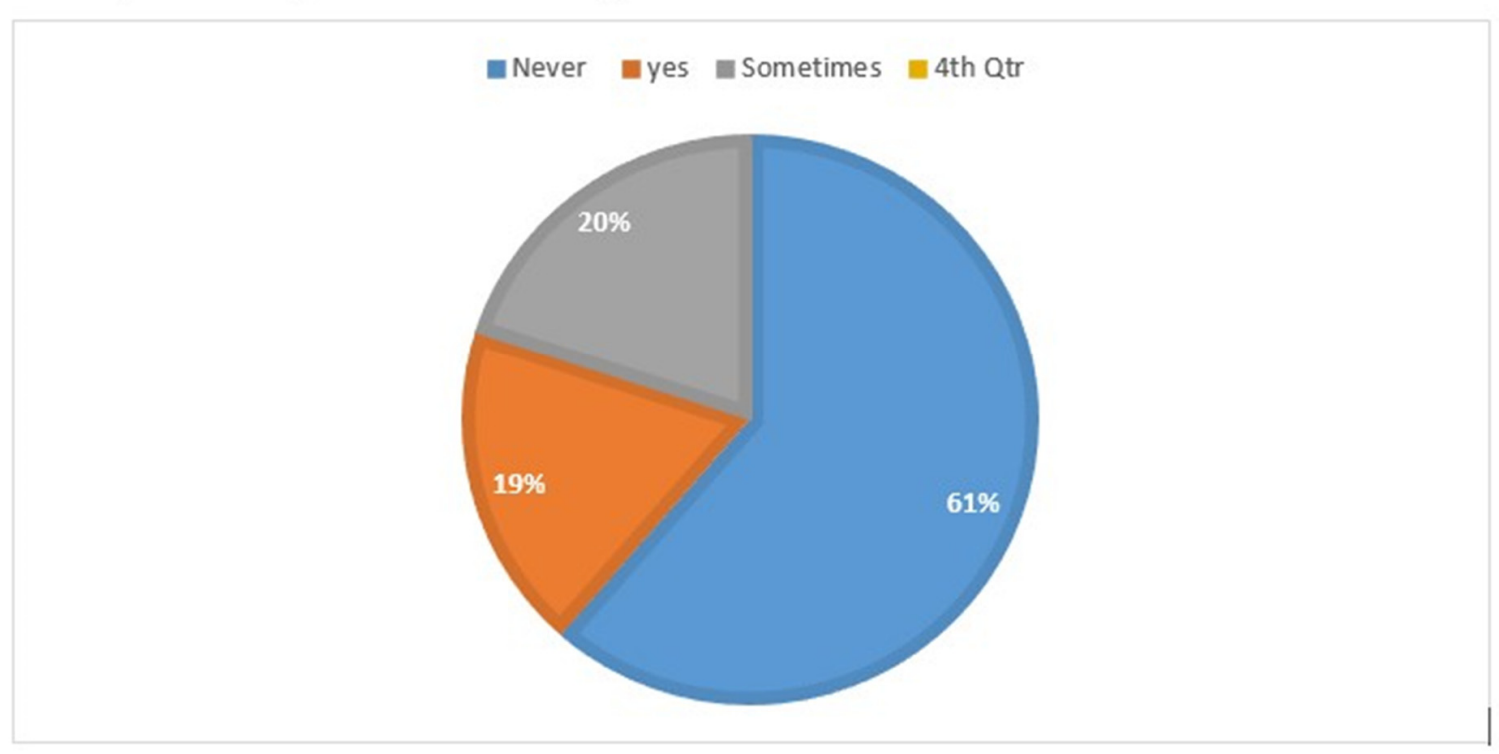


avez vous jamais regretté d'avoir délivré vos informations?

90 réponses

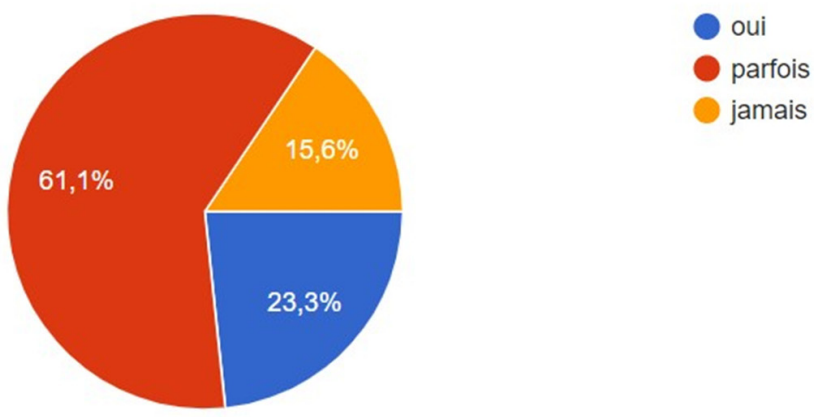

if you changed your attitude towards social networks after Facebook was fined a record $\$ 5$ billion for improper storage of user data?

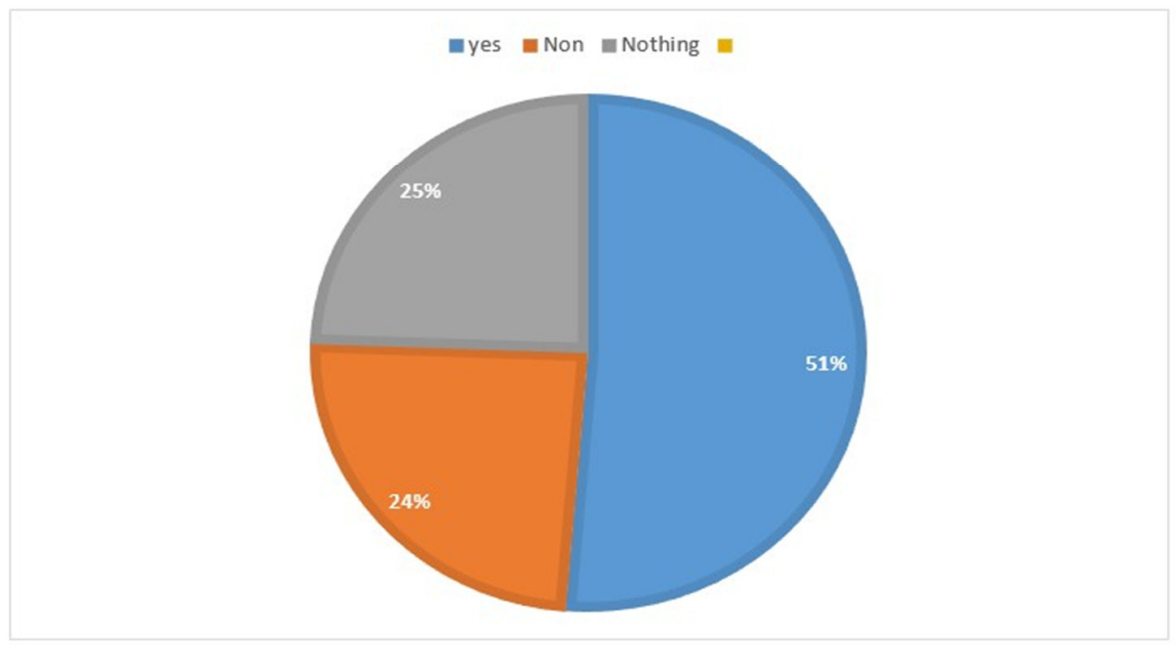

Avez vous modifié votre attitude envers les réseaux sociaux après la sanction de Facebook de 5 milliard d' euros https://www.france24.com/fr/20190724-facebook-accepte-amendemilliards-dollars-ftc-record-critiques

89 réponses

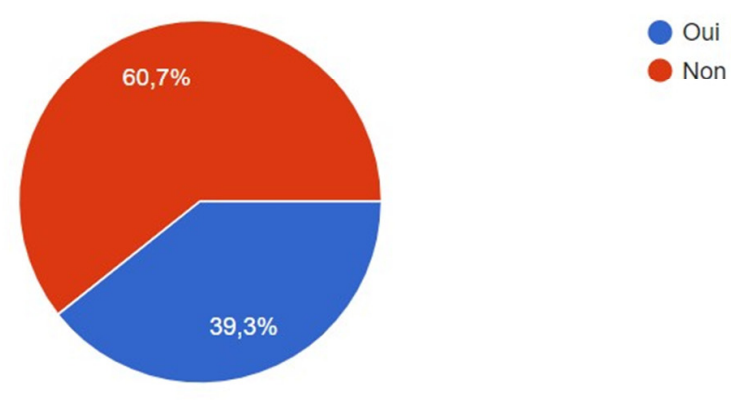


In case of improper processing of your personal data, do you intend to apply to the relevant authority for protection?

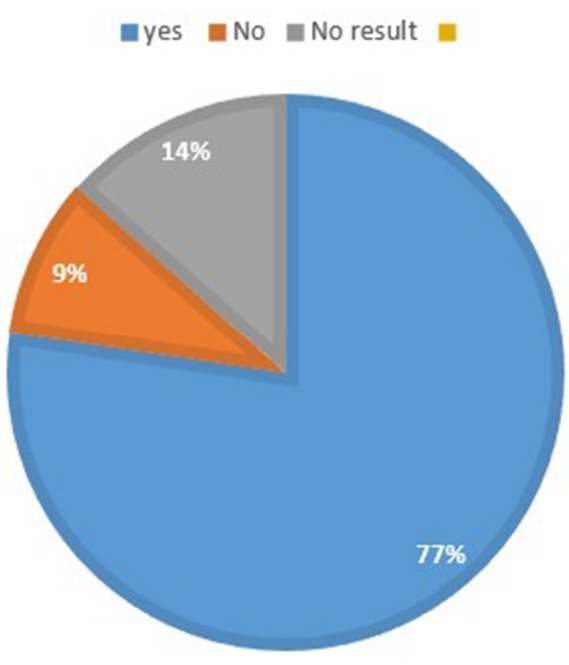

Vous adresserez vous aux organisations compétentes pour la défense de vos droits au cas de l'abus?

90 réponses

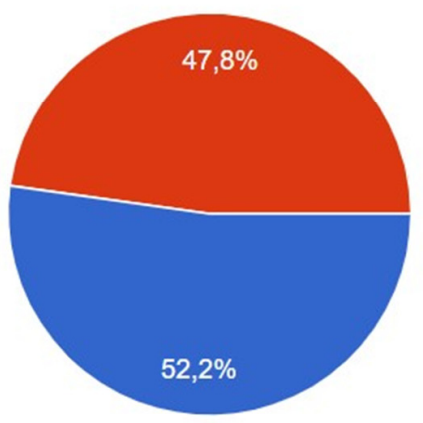

Oui

Non 
The right to be forgotten is one of the most important points in the general regulation of personal data protection in 2018, which was used by thousands of Internet users. What is your opinion on this issue?

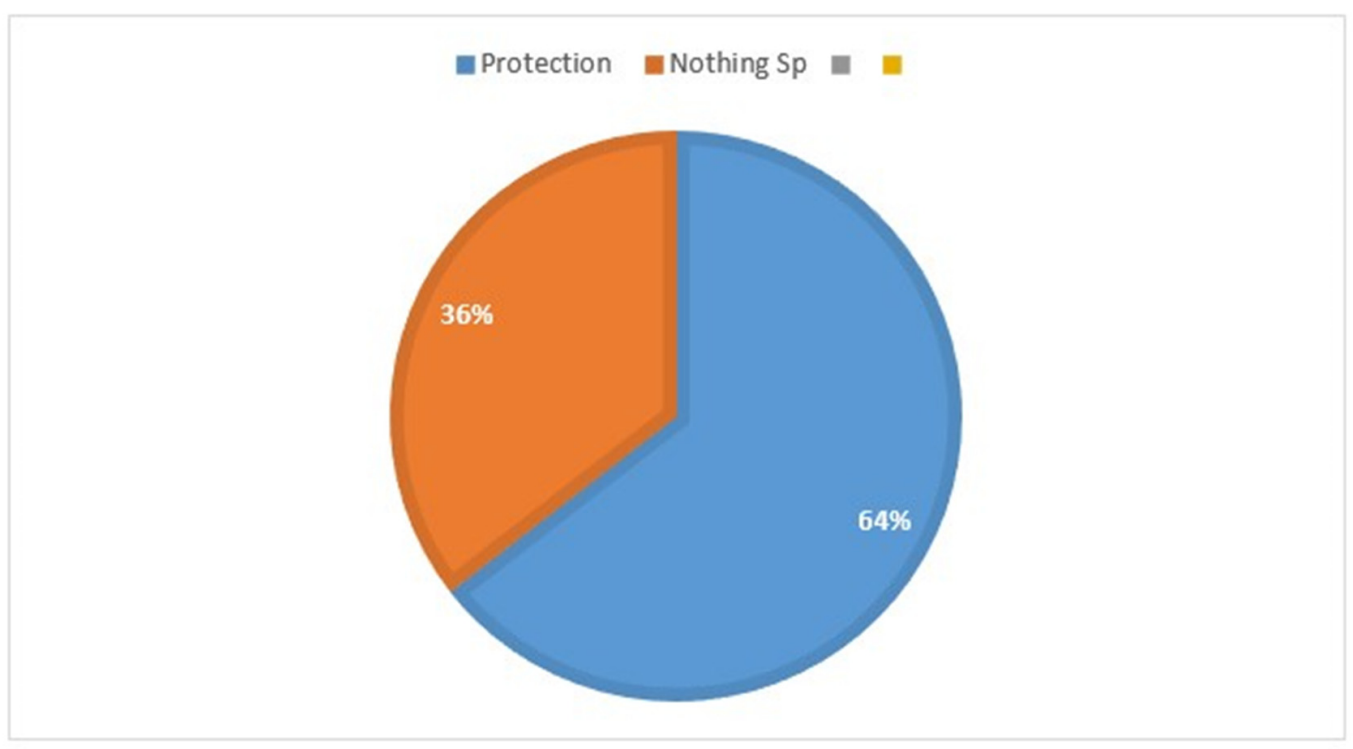

Quel est pour vous le droit à l'oublie

85 réponses

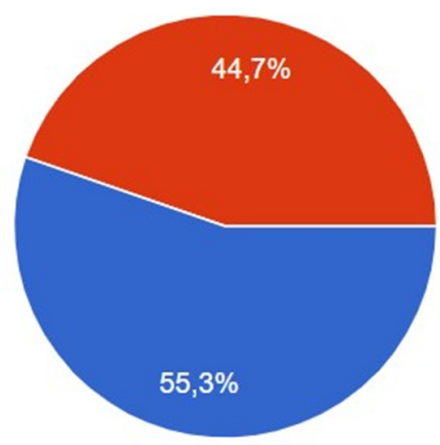

défense renforcée contre la discrimination

rien particulier 
Have you heard about GDPR regulation?

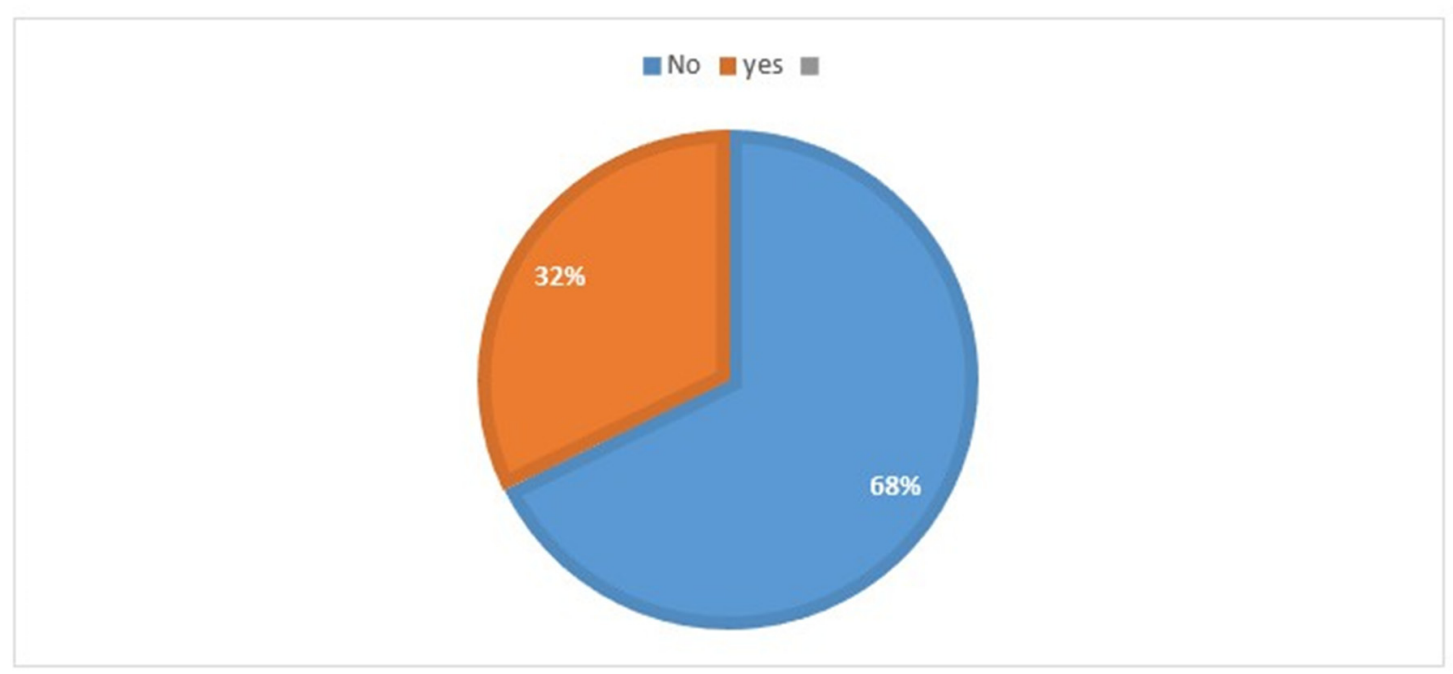

Connaissez vous le RGPD

90 réponses

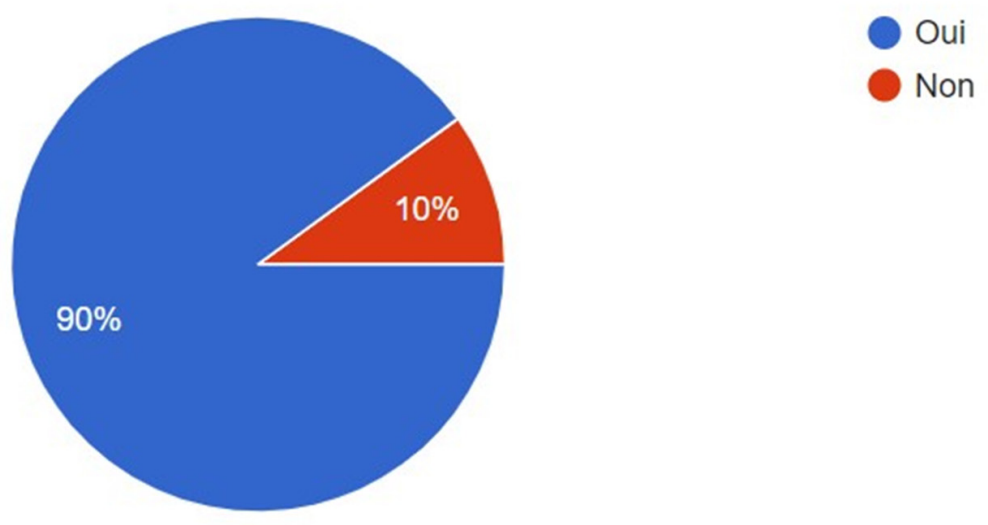


In France, since 2018, There Is an information system on orientation in higher education "système d'information sur l'orientation dans le supérieur". According to the creators, this system helps to see the existing problems and interests in order to improve them in the future. Complete information about each pupil and student is gathered from school to the University period. Do you think it is justified to have a similar system and use the same practice in Georgia?

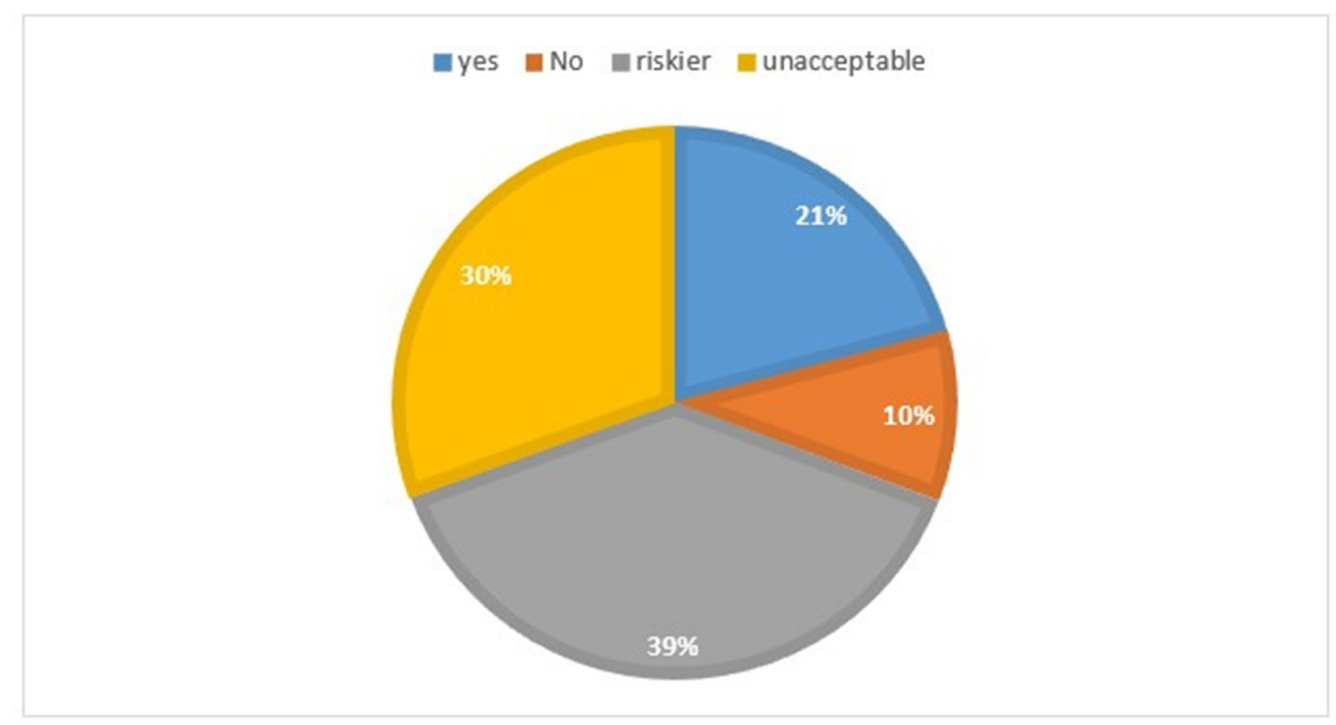

Arrêté du 23 novembre 2018 portant création d'un traitement automatisé de données à caractère personnel dénommé «Système d'information sur l'orientation dans le supérieur » (ORISUP) Qu' es ce que c' est pour vous?

86 réponses

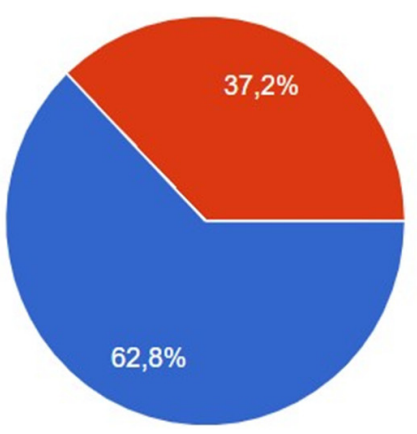

un traitement de données qui retrace tout le parcours des étudiants, avec un luxe de détails, à des fins statistiques et de recherche.

danger pour la protection des données 


\section{Results of the research}

The research outcomes suggest that both Georgian and French respondents are often concerned about their own voluntary disclosure of personal information. The colossal fines imposed on social networks have caused sharp distrust among users following the famous scandal. The "right to be forgotten" is perceived by consumers as a sharp mechanism to stop discriminatory treatment. Georgian students are skeptical about the introduction of such a system in higher education (0RISUP) and believe that in the reality of our country, a similar idea in terms of personal data protection will be more risky. As for the case of improper processing of data, $77.1 \%$ of Georgian respondents in this paragraph think that they apply to the appropriate authorities to protect their rights, while only $52.2 \%$ of French students surveyed intend to fight for their rights.

\section{Conclusion}

In the 1990s, companies were satisfied with gathering information related to the market (market shares, customer characteristics, etc.). Currently, they target specific data for each consumer, his characteristics, his consumption preferences. At the time, collection was done face to face or by phone, or by mail. Today, new technology has completely changed the situation. Data collection, storage and transmission are carried out at high speed across the world. On the one hand, technology has evolved, but on the other hand it has raised the issue of privacy protection. For businesses, collecting and processing data is a strategic matter that must be addressed on the one hand by law and on the other hand by personal ethics. When studying the protection of personal data, we quickly notice that several sciences are interested in this subject. These include the interest of "marketologists" in collecting customer data. Equally great is the interest and opinions of sociologists, psychologists and computer scientists on this subject.

In sociology, we talk about a social contract, a form of exchange in which individuals engage in return for economic or social benefits. The notion of "social contract" implies understanding that individuals are willing to provide personal information if they find a suitable consideration. In psychology, it has been found that giving out information about one's personality is a phenomenon linked to the development of intimacy. Private life would be a base on which privacy can be built.

The variety of responses to this topic raises the question of what privacy consists, and where the line lies between personal data and commercial and security interests. There are several books on self-disclosure which is defined as the process by which one gives personal information to others. The individual lives in society and has regular exchanges with other individuals, members of this group.

We can distinguish two types of exchanges in our societies:

- Economic exchange (when "goods" can be exchanged for their monetary equivalent);

- Social exchange, which can be defined as an exchange in which one of the two partners can engage without knowing exactly the consideration that will be offered to him. ${ }^{29}$

Business satisfaction can be influenced by different factors, an individual's geographic origin or the tastes of individuals. According to a French sociologist, every individual is a "homo oeconomicus" who optimizes his profits without necessarily seeking symbolic or psychological retribution. ${ }^{30}$

\footnotetext{
${ }^{29}$ P. Blau, Exchange and Power in Social Life, eBook Published25 October 2017.

${ }^{30}$ Pierre Demeulenaer « Homo oeconomicus », Presse Universitaires de France, 2003.
} 


\section{BIBLIOGRAPHY}

1. Facebook : une amende de 5 milliards de dollars et de nouveaux garde-fous, déjà contestés 24.072019 https://www.lemonde.fr/pixels/article/2019/07/24/donnees-personnelles-les-etats-unis-imposent-de-nouveauxgarde-fous-a-facebook-deja-contestes_5493017_4408996.html [Last seen 28.11.2021];

2. Liberté de l'establishment, Journal du droit international (Clunet), N3. 2009-07-01. GAILLARD Emmanuel, Racine Jean-Baptiste;

3. Serge Findling, Joseph C. Pucciarelli, Michael Jennett; IDC FutureScape: Worldwide CIO Agenda 2018 Predictions 2017 https://www.idc.com/getdoc.jsp?containerId=US43203417\&pageType=PRINTFRIENDLY [Last seen 27.11.2021];

4. Big data et analytique : un marché promis à une croissance à deux chiffres 18.07.2021 https://www.silicon.fr/bigdata-analytique-croissance-414574.html\#: :text=Actualit\%C3\%A9s\%20Big\%20Data-

,Big\%20data $\% 20$ et $\% 20$ analytique $\% 20 \% 3 \mathrm{~A} \% 20$ un $\% 20$ march $\%$ C3\%A $\% \% 20$ promis,une $\% 20$ croissance $\% 20 \%$ C3 \%A0\%20deux\%20chiffres\&text=Selon\%20les\%20plus\%20r\%C3\%A9centes\%20pr\%C3\%A9visions,de \%20dol lars\%20cette\%20ann\%C3\%A9e\%202021. [Last seen 27.11.2021];

5. E-learning - Chiffres et tendances du marché 8.04.2020 https://www.callimedia.fr/e-learning-chiffres-ettendances-du-marche/ [Last seen 28.11.2021];

6. BAROMÈTREE-LEARNING2020"6.02.2020://www.afinef.net/wp-content/uploads/2020/07/BarometreAFINEF-Digital-Learning-2020-Presse.pdf [Last seen 29.11.2021];

7. L'article 226-4-1 du Code pénal;

8. GAFA,GAFAM ou NATU: les nouveaux maîtres du monde 29.07.2021 https://www.lafinancepourtous.com/decryptages/finance-et-societe/nouvelles-economies/gafa-gafam-ou-natules-nouveaux-maitres-du-monde/ [Last seen 29.11.2021];

9. Les Français et la protection des données personnelles », études de l'Institut du CSA pour Orange, 2014;

10. Droit à l'oubli : la Cnil dit non au recours de Google, La Tribune. 21.09.2015 https://www.latribune.fr/technosmedias/internet/droit-a-1-oubli-la-cnil-dit-non-au-recours-de-google-506908.html [Last seen 29.11.2021];

11. Arrête Google Spain c/ AEPD et Costeja Conzales, 13/05/2014. Demande de décision préjudicielle, introduite par l'Audiencia Nacional.

12. GDPR; Droitàl'effacement "droitàl'oubli" Article17, https://www.gdprexpert.eu/article.html?id=17\#textesofficiels [Last seen 29.11.2021];

13. GDPR Right to object, Art. 21 https:/gdpr-info.eu/art-21-gdpr/ [Last seen 29.11.2021];

14. Fabien Hanna, Etude «Value Me» de Microsoft Advertising sur la valorisation des données personnelles. 20.07.2015 [Last seen 29.11.2021];

15. Milad Doueihi, Digital Cultures, (2011a). En traduction française, La grande conversion numérique 2008;

16. Peppe Cavallar, La culture numérique selon Dominique Cardon, Culture numérique, Presses de Sciences Po, 2019;

17. Explanatory Report to the Convention on Cybercrime Budapest. $23.11 .2001 \mathrm{https}: / / \mathrm{rm} . c 0 e . i n t / 16800 \mathrm{cce} 5 \mathrm{~b}$ [Last seem 29.11.2021];

18. Loi ${ }^{\circ} 2000-230$ du 13 mars 2000 portant adaptation du droit de la preuve aux technologies de l'information et relative à la signature électronique;

19. Loi n ${ }^{\circ} 2004-575$ du 21 juin 2004 pour la confiance dans l'économie numérique;

20. LESCHIFFRESCLÉS2019FÉDÉRATION E-COMMERCE ET VENTE À DISTANC https://www.fevad.com/wp-content/uploads/2019/06/Chiffres-Cles-2019_BasDef-1.pdf [Last seen 29.11.2021];

21. Key figures on Europe $2021 \mathrm{https} / /$ ec.europa.eu/eurostat/documents/3217494/13394938/KS-EI-21-001-ENN.pdf/ad9053c2-debd-68c0-2167-f2646efeaec1 [Last seen 30.11.2021];

22. P. Blau, Exchange and Power in Social Life, eBook Published25 October 2017;

23. Pierre Demeulenaer „Homo oeconomicus“, Presse Universitaires de France, 2003. 